\title{
A Prospectus for Inclusion: Project study for a potential education solution for Syria's Persons with Disability (PwDs)
}

\author{
Ammar Almustafa, Ahmad Alashkar \\ American University of Beirut, Beirut, Lebanon. \\ ammar.almostapha@gmail.com \\ ahmad.blond@gmail.com
}

\begin{abstract}
The article proposes an innovative solution to the problems in the access and quality of STEM concepts education to Persons Living with Disability (PwD) in Syria. A project management-based approach is detailed below for a cost-effective method to be implemented by non-governmental organizations or public agencies.
\end{abstract}

Keywords: Persons with Disability, PwD, E-learning, MOOC, Disability Advocacy, Syria, Refugees, waraffected populations, online learning.

Biographical notes: Ammar Almustafa is a psychologist specializing in addiction science with four years of experience in the non-profit sector. Ammar is certified in Associate Project Management by the American University of Beirut. Ahmad Alashkar is a marketing graduate and a published filmmaker with seven years' experience in project-based work. He is certified in Associate Project Management by the American University of Beirut.

Acknowledgements: Dr. Eli Nohra, Professor of Project Management at the American University of Beirut. Ali Ekriem, Founder and CEO of Emaa organization for special education.

\section{Introduction}

In 2009, the number of people with disabilities in Syria was estimated to be 2 million, of which over 700,000 were children. Prevalence of disability is estimated to be $10 \%$ of the population (Said Foundation, 2009). Syria is a home for 153,000 blind individuals (Mariotti, 2012) and 200,000 individuals with hearing loss (Krayem, 2010). But now, these numbers would likely increase by $18-20 \%$ due to conflict. (Skinner, 2014)

Moreover, a study by the British Syria Relief organization on the needs of youth Persons with Disabilities (PwDs) in Syria showed that $64 \%$ of the participants indicated a need for education services (Tchie, \& Tkacova, 2018). This is exacerbated by the fact that Syria as of 2013, had only 31 governmental centers distributed in several governorates, besides only 65 local organizations working for the rehabilitation and education of Persons with Disabilities, out of 2,000 registered NGO in Syria. (Permanent Mission of the Syrian Arab Republic to the United Nations, 2013).

Syria is one of the last Arab states that doesn't have a special curriculum adopted for the hearing impaired. Hearing impaired students are required to filter through two layers of communication to acquire a new piece of info. This is due to the lack of training and standardization in educational sign language. (Ibrahim, 2010)

It's also noted that there is discrimination in providing health services for women with disabilities. Youth living with disabilities are often disregarded in sexual awareness, leaving them denied the tools for the prevention of STDs, assault and forced pregnancy. (Women Enabled International, 2017)

PwDs are often excluded from aid programs, and ignored when humanitarian organizations establish targeted services, especially in delicate and conflict-related settings. This is due to a bundle of mental and physical 
barriers. (Tchie, \& Tkacova, 2018) By providing an online platform, named Akkazeh (the Arabic term for Cane) our project intends to bypass the obstacles of the rarity of braille and special materials in Syria, inflexibility in time and place, the scarcity of speakers in sign language, stigma and bullying, as well as stultified curricula.

This project aims to create a website hosting Massive Open Online Courses (MOOCs) specifically designed for the blind, hearing impaired, and Motor-Impaired persons, to foster inclusion and help these individuals pass their mandated official exams in grades nine through twelve. In addition, it will host videos and articles to raise awareness for and about Persons with Disabilities (PwDs).

\section{Scope}

This project will span about 18 months with 20 team members, and a number of volunteers to assist the production of 150 videos, 75 audio clips and 100 articles, through seven production cycles for audio-visual materials. The scope includes planning, execution, and operation of a modern, user-friendly website, audiovisual content, and a social media network. This entails an interview-based needs assessment of a representative sample of the PwD population in Syria. Further content such as articles, social media posts, and advertising campaigns will be published starting the sixth month of implementation.

The target group is Syrian people (between $15-45$ years) with physical, visual or hearing impairments and their respective communities. This project will not be targeting people with psychiatric, neurological or intellectual disabilities. The project is also not responsible for issuing legally-binding educational certificates, nor does it replace the current official infrastructure in education and training.

\section{Strategy}

Akkazeh will be incorporating volunteers from Eemaa's team (A local non-government organization) as actors in the production phases, as well as consultants on content from its in-person teachers. This will help identify key gaps in modifying the information to accessible curricula for the clients.

Moreover, a needs assessment phase is conducted at the beginning of the implementation to ensure the relevance of the subjects to be discussed on the website. The project management will also make use of the fact that PWD communities are often exclusive and thus word-of-mouth can travel very fast to ensure the required number of participants.

The platform will be adjusted to work on mobile phones as well as research shows that Syrian vulnerable populations are more likely to depend more on mobile phones to access the internet. (UNHCR, 2016) The content will be selective in nature so that prospective students will be able to pick the subject they would like to learn about from a variety of options. For example, under physics: capacitors, conduction, light properties...etc. 


\begin{tabular}{|c|c|c|c|}
\hline Structure & Indicator & Means of Verification & Assumptions \\
\hline \multicolumn{4}{|l|}{ Goal } \\
\hline $\begin{array}{l}\text { PwD population living in } \\
\text { Syria empowered. }\end{array}$ & $\begin{array}{l}\text { Akkazeh platform climbed to the } \\
\text { top } 300 \text { ranking for website } \\
\text { traffic in Syria. }\end{array}$ & $\begin{array}{l}\text { Reported in top } 300 \text { in } \\
\text { Alexa's Ranking on Syria at } \\
\text { End of } 2020 .\end{array}$ & \\
\hline $\begin{array}{l}\text { PwD population is better } \\
\text { equipped for inclusion. }\end{array}$ & $\begin{array}{l}* 9,000 \text { of estimated blind and } \\
\text { deaf individuals were } \\
\text { introduced to alternative } \\
\text { education. } \\
* * 9,000 \text { Persons with Physical } \\
\text { disability introduced to } \\
\text { alternative professional training. }\end{array}$ & Project termination report. & \\
\hline \multicolumn{4}{|l|}{ Purpose/Objective } \\
\hline $\begin{array}{l}* * * 60,000 \text { individuals } \\
\text { reached by dedicated } \\
\text { online campaigns. } \\
\text { (targeting the users' } \\
\text { families) }\end{array}$ & $\begin{array}{l}\text { Knowledge among base } \\
\text { increased from baseline }\end{array}$ & $\begin{array}{l}40-55 \% \text { Bounce rate on } 60 \mathrm{~K} \\
\text { views to Akkazeh's website. } \\
\text { Analytics software report \& } \\
\text { Social media surveys. }\end{array}$ & $\begin{array}{l}\text { Lucrative online } \\
\text { advertising will } \\
\text { increase views and } \\
\text { participation since } \\
\text { the need exists. }\end{array}$ \\
\hline $\begin{array}{l}\text { Online education is } \\
\text { available to } 5,500 \text { deaf } \\
\text { individuals. }\end{array}$ & 5,500 deaf individuals registered & Website's monthly report. & \multirow{3}{*}{$\begin{array}{l}\text { PwD populations } \\
\text { are smaller and } \\
\text { have similar means } \\
\text { of communication } \\
\text { which can facilitate } \\
\text { the transfer of } \\
\text { information. }\end{array}$} \\
\hline $\begin{array}{l}\text { Online education is } \\
\text { available to } 3,500 \text { blind } \\
\text { individuals. }\end{array}$ & $\begin{array}{l}3,500 \text { blind individuals } \\
\text { registered }\end{array}$ & Website's monthly report. & \\
\hline $\begin{array}{l}\text { Online professional } \\
\text { training is available to } \\
9,000 \text { Persons with } \\
\text { physical disabilities. }\end{array}$ & $\begin{array}{l}\text { 9,000 Professional training } \\
\text { participants registered }\end{array}$ & Website's monthly report. & \\
\hline \multicolumn{4}{|c|}{ Outputs/Deliverables } \\
\hline $\begin{array}{l}\text { Website and Social } \\
\text { media presence on } \\
\text { Facebook, YouTube and } \\
\text { Instagram established. }\end{array}$ & $\begin{array}{l}\text { Social media referrals } \\
\text { significantly contributed to the } \\
60 \mathrm{~K} \text { views on the website } \\
\text { objective. }\end{array}$ & $\begin{array}{l}\text { Analytics software report \& } \\
\text { Website visit. }\end{array}$ & $\begin{array}{l}\text { Internet usage in } \\
\text { Syria will not } \\
\text { deteriorate further } \\
\text { since the war is in } \\
\text { its final stages. }\end{array}$ \\
\hline $\begin{array}{l}50 \text { Videos targeting } \\
\text { community about PwD } \\
\text { rights, and social \& } \\
\text { health awareness were } \\
\text { produced and } \\
\text { disseminated. }\end{array}$ & $\begin{array}{l}50 \text { videos are in working order } \\
\text { by the end of } 2020 .\end{array}$ & $\begin{array}{l}\text { Semi-annual website } \\
\text { benchmarking. }\end{array}$ & $\begin{array}{l}\text { Refugees are most } \\
\text { likely to use } \\
\text { Facebook and } \\
\text { Instagram according } \\
\text { to UN report. }\end{array}$ \\
\hline $\begin{array}{l}75 \text { Video lessons for the } \\
\text { deaf produced and } \\
\text { disseminated. }\end{array}$ & $\begin{array}{l}75 \text { Videos are In working order } \\
\text { by the end of } 2020 .\end{array}$ & $\begin{array}{l}\text { Semi-annual website } \\
\text { benchmarking. }\end{array}$ & $\begin{array}{l}\text { The target } \\
\text { population is a lot } \\
\text { more likely to use }\end{array}$ \\
\hline
\end{tabular}




\begin{tabular}{|l|l|l|l|}
\hline $\begin{array}{l}75 \text { Audio lessons for the } \\
\text { blind produced and } \\
\text { disseminated. }\end{array}$ & $\begin{array}{l}75 \text { audios are in working order } \\
\text { by the end of } 2020 .\end{array}$ & $\begin{array}{l}\text { Semi-annual website } \\
\text { benchmarking. }\end{array}$ & $\begin{array}{l}\text { phones, so a phone- } \\
\text { based approach } \\
\text { would work. }\end{array}$ \\
\hline $\begin{array}{l}25 \text { professional training } \\
\text { videos for persons with } \\
\text { physical disability } \\
\text { produced and } \\
\text { disseminated. }\end{array}$ & $\begin{array}{l}25 \text { videos are in working order } \\
\text { by the end of } 2020 .\end{array}$ & $\begin{array}{l}\text { Semi-annual website } \\
\text { benchmarking. }\end{array}$ & \\
\hline $\begin{array}{l}100 \text { Articles discussing } \\
\text { disability issues } \\
\text { published/posted. }\end{array}$ & $\begin{array}{l}100 \text { Articles are in working order } \\
\text { by the end of } 2020 .\end{array}$ & $\begin{array}{l}\text { Semi-annual website } \\
\text { benchmarking. }\end{array}$ & \\
\hline & & & \\
\hline
\end{tabular}

\section{Acceptance Criteria}

The acceptance criteria are put in place to ensure that the project's outputs will be achieving its objectives, please refer to LogFrame for further info and Theory of Change (ToC). The criteria are mostly quantitative and all of it must be met in order to achieve success for this project:

- $\quad$ Criterion 1: Meet all deliverables within scheduled time and budget tolerances.

- $\quad$ Criterion 2: 60,000 individuals reached by dedicated campaigns (targeting the users' families and surrounding community).

- $\quad$ Criterion 3: Online education introduced to 5,500 deaf individuals.

- Criterion 4: Online education introduced to 3,500 blind individuals

- $\quad$ Criterion 5: Online database reaching to 9,000 Persons with physical disabilities.

\section{Project Milestones}

The duration of the project is 18 months, includes 400 working days.

\begin{tabular}{|c|c|c|c|}
\hline Milestones & Duration & Cumulative Duration & $\begin{array}{c}\text { Cumulative } \\
\text { Budget }\end{array}$ \\
\hline 1. Needs Assessment & 35 Days & $8.86 \%$ & $\$ 3,655$ \\
\hline 2. Recruitment Phase & 30 Days & $16.46 \%$ & $\$ 6,788$ \\
\hline 3. Opening Phase & 80 Days & $36.71 \%$ & $\$ 41,905$ \\
\hline 2.1. Pre-Production & 35 Days & $25.32 \%$ & $\$ 22,152$ \\
\hline 2.2. Production & 10 Days & $27.85 \%$ & $\$ 26,541$ \\
\hline 2.3. Post-Production & 35 Days & $36.71 \%$ & $\$ 41,905$ \\
\hline 4. Operation Phase & 235 Days & $97.47 \%$ & $\$ 147,256$ \\
\hline 3.1. Production Cycle 1 & 60 Days & $46.84 \%$ & $\$ 59,463$ \\
\hline 3.2. Production Cycle 2 & 60 Days & $56.96 \%$ & $\$ 77,022$ \\
\hline 3.3. Production Cycle 3 & 60 Days & $67.09 \%$ & $\$ 94,580$ \\
\hline 3.4. Production Cycle 4 & 60 Days & $77.22 \%$ & $\$ 112,139$ \\
\hline 3.5. Production Cycle 5 & 60 Days & $87.34 \%$ & $\$ 129,697$ \\
\hline 3.6. Production Cycle 6 & 60 Days & $97.47 \%$ & $\$ 147,256$ \\
\hline 5. Closure Phase & 20 Days & $100.00 \%$ & $\$ 148,375$ \\
\hline
\end{tabular}




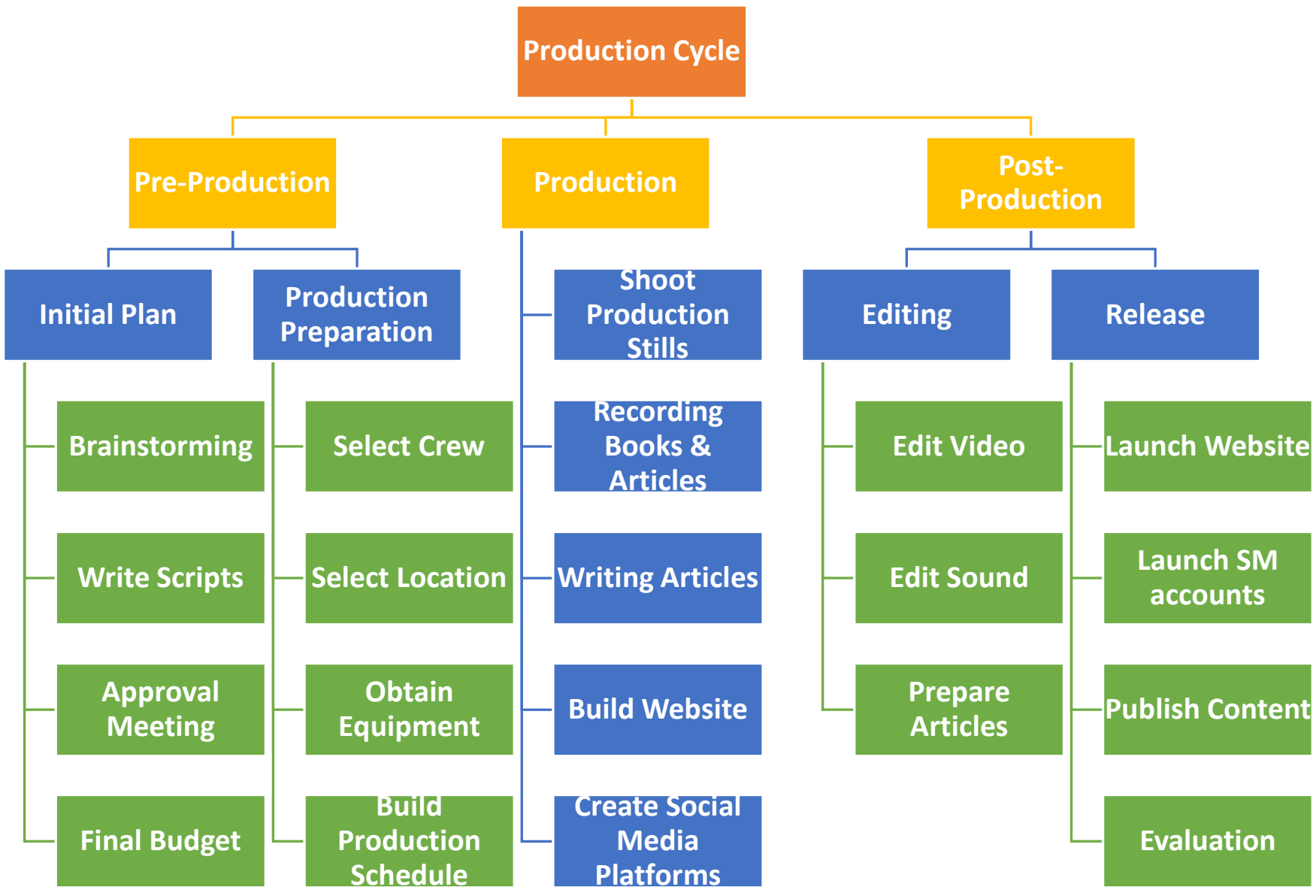

\section{Examples of Content}

\section{For Persons with disabilities}

- A database of health and support help (medical, educational) providing centers.

- A database of companies providing handicapped related products.

- Provide access to freelance jobs that are a PwDs is capable of handling (programming, translation, voice recording).

- Tips and hints on how to deal with your recent health and motor situation for persons who acquired new disabilities.
Awareness about PwD issues

- Materials dedicated to raising awareness among the society on PwDs rights.

- Materials raising awareness on how the disability is acquired, and how to avoid it if possible.

- Materials facing discrimination against PwDs, especially Females, e.g. discrimination at work and marriage.

- PwDs Telling jokes on some of their daily hardships, e.g. dealing with the street pavement.

- How the community contributes to supporting issues of PwDs, e.g. simple structural changes in buildings that can make lives of PwDs easier. 


\section{SWOT Analysis}

\begin{tabular}{|c|c|c|c|}
\hline 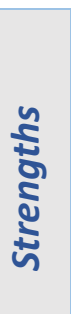 & $\begin{array}{l}\text { - Long experience with Eemaa on adjusting } \\
\text { material for PwD accessibility. } \\
\text { Availability of motivated team due } \\
\text { personal connection with the subject. } \\
\text { - Modern technology in providing massive } \\
\text { open online courses. }\end{array}$ & 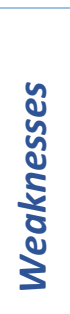 & $\begin{array}{l}\text { - Lack of experience in mobile development } \\
\text { - } \quad \text { No offite. } \\
\text { - Online education can sustain high drop- } \\
\text { out rates. }\end{array}$ \\
\hline 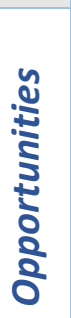 & $\begin{array}{l}\text { - Demonstrated high need in the } \\
\text { community. } \\
\text { - The project's benefits (educational } \\
\text { material) will remain online. } \\
\text { - The project is a trail blazer in its category } \\
\text { for education. }\end{array}$ & 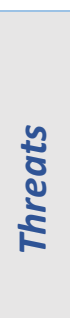 & $\begin{array}{l}\text { - Internet in Syria can be unreliable in some } \\
\text { provinces. } \\
\text { - Major online advertisers (Google and } \\
\text { Facebook) don't operate in Syria. } \\
\text { Distance learning is a relatively new } \\
\text { concept in Syria. }\end{array}$ \\
\hline
\end{tabular}

\section{Risk Management Plan}

\section{Risk}

a) High course drop-out rate

Likelihood: $80-100 \%$ Impact: High

b) Website going offline

Likelihood: $30-60 \%$

Impact: High

c) Social Media accounts going offline

Likelihood: $30-60 \%$

Impact: Medium

d) Cast/crew injury, sickness, or unavailability

Likelihood: $30-60 \%$

Impact: Low

e) Equipment malfunction

\section{Details}

The literature records drop-out levels for on-line courses of $25 \%$ to $45 \%$ compared to $10 \%$ to $20 \%$ for face-to-face classes (Levy, 2007*). Reasons for drop-out include: Student' unfamiliarity with online learning, Teacher's attitudes, perceptions of ease of use, and variations in assessment.

The website could get hacked or there could be a malfunction due to server pressure.

Accounts hacked or content incompatible with platform policies.

\section{What we should do}

Tutorials will be included, Active customer service created, Measures to reinforce ease of use during the design implemented, Methodological assessment used.

Offline site back-ups are regularly saved.

Account protection using the various verification methods offered by the platforms, in addition to being wary of the platforms' posting policy.

Schedules will be disseminated far in advance, buffer time accounted for in the schedule for changes. List of backup crew to be to be identified as well. shoot.

Camera, lighting, sound, or other

Recruited crew are of reputable equipment being used in the video shoot may malfunction. 
Likelihood: $30-60 \%$

Impact: Low

f) Unforeseeable postproduction difficulties

Likelihood: $30-60 \%$

Impact: Medium

g) Material publishing delays

Likelihood: $0-30 \%$

Impact: High

h) Location or Studio disaster

Likelihood: $0-30 \%$

Impact: High in addition to ensuring a back-up equipment lessor.

Video and audio editing during postproduction may prove to be more difficult than we planned for, thus causing schedule or cost overruns.

Production delays could lead to publishing delays.
Sticking tightly to the shooting script, using bottom up budgeting to get accurate estimates, finalizing all revisions to the script prior to shooting, and carefully examining delays should they happen. Contingency plans to be made, and over-time can be reinstated to meet the deadlines.

\section{Appendix: LogFrame estimates}

*9,000: The estimation was made based on several studies:

- The cumulative number of blind individuals living in Syria according to WHO estimates is around 153,000 (Mariotti, 2012)

- The cumulative number of persons with hearing loss in Syria is around 200,000 according to our NGO (Eemaa) that concerns itself with hearing impairment affairs.

- Digital divide studies from several developed countries show that PwDs are less than half as likely to use the internet. For the purposes of this project we will consider a rate of 30\% (Duplaga, 2017; Kaye, 2003)

- According to ITU report, only around $13 \%$ of people in the least developed countries have ICT access. (International Telecommunication Union, 2015)

- According to a study on the needs of PwD youth in Syria, $65 \%$ of the sample reported the need for educational services. (Tchie, \& Tkacova, 2018)

Our target for this project will then be calculated as follows:

$(200 \mathrm{~K}+153 \mathrm{~K}) \times 0.3 \times 0.13 \times 0.65 \approx 9,000$ Users

**9,000: The target audience number is fit to Massive open online course and advertisement bundles' costs.

$* * * 60,000$ : Assuming a family of 5 individuals per participant. 


\section{References}

Duplaga, M. (2017). Digital divide among people with disabilities: Analysis of data from a nationwide study for determinants of Internet use and activities performed online. PLOS ONE. Poland.

Ibrahim, S. (2010). Syria's deaf survive against all odds. Arab Reporters for Investigative Journalism (ARIJ). Accessed from: https://en.arij.net/report/syrias-deaf-survive-against-all-odds

International Telecommunication Union. (2015). Measuring the Information Society Report. United Nations. Geneva, Switzerland.

Kaye, S. (2003). Disability and the digital divide: accounting for lower levels of computer and internet usage among people with disabilities. 131st Annual Meeting of APHA, November 15-19.

Krayem, A. (2010). Teaching the Deaf Project. Emaa Organization. Damascus, Syria.

Levy, Y. (2007). Comparing dropouts and persistence in e-learning courses. Computers \& Education, 48(2), 185-204.

Mariotti, S.P. (2012). Global Data on Visual Impairments. World Health Organization. Geneva, Switzerland.

Permanent Mission of the Syrian Arab Republic to the United Nations. (2013). Opportunities for Persons with Disability in the Education Sector in Syrian Arab Republic. Registry of the office of the High Commissioner for Human Rights. Geneva, Switzerland.

Said Foundation. (2009). Syria programme - Five-year plan. from: https://www.mindbank.info/download_file/1619/fdaa3715b445f9621683662dd3865c73ea0920ea

Skinner M. 2014. The impact of displacement on disabled, injured and older Syrian refugees. Forced Migration Review 47.

Soulaf Ibrahim. (2010). Syria's deaf survive against all odds. Arab Reporters for Investigative Journalism (ARIJ). Accessed from: https://en.arij.net/report/syrias-deaf-survive-against-all-odds

Tchie, A.E., \& Tkacova, K. (2018). Children living with disabilities inside Syria research report: Understanding the types of disabilities and access to services for children living in Syria. Syria Relief. London, United Kingdom.

UNHCR. (2016) Connecting Refugees: How Internet and Mobile Connectivity Can Improve Refugee Well-Being and Transform Humanitarian Action. UNHCR's Division of Information Systems and Telecommunications (DIST). Geneva, Switzerland.

Women Enabled International. (2017). Sexual and Reproductive Health and Rights of Women and Girls with Disabilities. Washington, D.C. 